ORIGINAL ARTICLE

\title{
Sports and recreation related injury episodes in the US population, 1997-99
}

\author{
J M Conn, J L Annest, J Gilchrist
}

Injury Prevention 2003;9:117-123

\begin{abstract}
Objective: To characterize sports and recreation related (SR) injury episodes in the US population. SR activities are growing in popularity suggesting the need for increased awareness of SR injuries as a public health concern for physically active persons of all ages in the US population.

Setting: The National Health Interview Survey (NHIS) is a face-to-face household survey conducted yearly by the National Center for Health Statistics, part of the Centers for Disease Control and Prevention. Demographic and health data are collected from a nationally representative sample of the civilian, non-institutionalized population residing in the US.

Methods: Medically attended injury events reported in the 1997-99 Injury Section of the NHIS were categorized according to the associated sport or recreational activity using a classification scheme based on the International Classification of External Causes of Injury system. Episodes where the injured person received any type of medical attention (that is, medical advice or treatment) from any health care provider were used to report the incidence, severity, and nature of SR injuries sustained by US citizens.

Results: Annually, an estimated seven million Americans received medical attention for SR injuries (25.9 injury episodes per 1000 population). For 5-24 year olds, this national estimate was about $42 \%$ higher than estimates based on SR injuries seen only in emergency departments over a similar time frame. The highest average annual SR injury episode rates were for children ages 5-14 years 159.3 per 1000 persons) and persons aged 15-24 years (56.4 per 1000 persons). The SR injury episode rate for males was more than twice the rate for females. The age adjusted injury rate for whites was 1.5 times higher than for blacks (28.8 v 19.0 per 1000 population). Basketball was the most frequently mentioned SR activity when the injury episode occurred, with a rate of about four injury events per 1000 population. Strains and sprains accounted for $31 \%$ of injury episodes. An estimated 1.1 million SR episode related injuries involve the head or neck region, of which $17 \%$ were internal head injuries. The most common mechanisms of injury were struck by/against $(34 \%)$, fall $(28 \%)$, and overexertion (13\%).

Conclusion: As physical activity continues to be promoted as part of a healthy lifestyle, SR injuries are becoming an important public health concern for both children and adults. Prevention efforts aimed at reducing SR injuries through targeting high risk activities, places of occurrence, activity, risk behaviors, and use of protective devices need to go beyond focusing on children and also consider physically active adults.
\end{abstract}

See end of article for

Correspondence to: Judith M Conn, Office of Statistics and

Programming, National Center for Injury Prevention and Control, Centers for Disease Control and Prevention, 4770 Buford Hwy (MS-K59), Atlanta, GA 30341-3724, USA jconn@cdc.gov
S udies of sports and recreation related (SR) injuries document their substantial public health impact both nationally ${ }^{1}$ and internationally. ${ }^{2-4}$ Based on a classification scheme derived from existing methodology, ${ }^{56}$ an estimated 6024 SR deaths occurred in the US in 1998; these deaths account for $4.1 \%$ of all injury related deaths (see table 1). During 1997 and 1998, there were an estimated 3.7 million SR emergency department visits annually in the US, representing about $11 \%$ of all injury related emergency department visits. Of these SR emergency department injury visits, more than $68 \%$, or 2.6 million visits, were among persons aged 5-24 years. The medical charges for these visits were estimated at \$500 million annually. Also during that time period, there were an estimated 4.3 million injury related episodes, or 91.2 episodes per 1000 children aged 6-17 years, where the child received medical attention for injuries associated with organized and unorganized sports or with recreational and leisure activities. ${ }^{8}$

Because SR injuries commonly occur among younger Americans, accounting for more than one fifth of all the injury emergency department visits by persons 5-24 year olds, most studies have focused on children and adolescents. ${ }^{8-14}$ Others have examined SR emergency department visits among "baby-boomers" and older Americans. ${ }^{15}{ }^{16}$ While previous reports focused predominantly on injuries treated in emergency departments, SR injuries are often treated by health care professionals in settings other than the emergency department. This paper presents national estimates across all ages for SR injury episodes where the injured person received any type of medical attention (that is, advice or treatment) by any health care provider.

\section{METHODS}

Data were obtained from the National Health Interview Survey (NHIS), a face-to-face household survey conducted yearly by the National Center for Health Statistics. Data are collected from a nationally representative sample of the civilian, non-institutionalized population residing in the United States. ${ }^{17}$ The NHIS was redesigned in 1997 and began using computer assisted personal interviewing. The Injury Section

Abbreviations: ICD-9-CM, International Classification of Diseases, Ninth revision, Clinical Modification, ICECI, International Classification of External Causes of Injury; NHAMCS, National Hospital Ambulatory Medical Care Survey; NHIS, National Health Interview Survey; SR, sports and recreation related 
Table 1 Estimated number of sports and recreation related (SR) injury deaths* based on selected ICD-9 external cause of injury codest: US, 1998

\begin{tabular}{|c|c|c|c|c|}
\hline Selected ICD-9 E codes & External cause description & $\begin{array}{l}\text { Total No of } \\
\text { deaths }\end{array}$ & $\%$ Applicable & $\begin{array}{l}\text { Estimated No } \\
\text { of SR deaths }\end{array}$ \\
\hline E800-E807(.3), E813.6, E819.6 & $\begin{array}{l}\text { Pedal cycle with a motor vehicle or } \\
\text { railway }\end{array}$ & 689 & 75 & 517 \\
\hline E826.1 & Pedal cycle & 118 & 100 & 118 \\
\hline $\mathrm{E} 828(.2, .3)$ & Animal drawn/ridden & 81 & 100 & 81 \\
\hline E820-E821 & Off-road vehicle & 294 & 100 & 294 \\
\hline E830-E838(.0,.1), E831 (.3,.9), E838.5 & $\begin{array}{l}\text { Accident to watercraft causing } \\
\text { submersion, drowning or fall, other } \\
\text { and unspecified water transport } \\
\text { accident }\end{array}$ & 203 & 100 & 203 \\
\hline E835.4, E838.4, E830.4, E831.4, E910.0 & Watersking & 7 & 100 & 7 \\
\hline E830(all but $.0, .1, .4$ ), E832(.3,.9), E910(.1,.2,.8) & Drowning & 3309 & 100 & 3309 \\
\hline E902.2, E883.0 & $\begin{array}{l}\text { Diving or jumping into water } \\
\text { causing injury other than drowning }\end{array}$ & 65 & 100 & 65 \\
\hline E842.6-E842.9 & Occupant unpowered aircraft & 19 & 100 & 19 \\
\hline E884.0, E886.0 & $\begin{array}{l}\text { Falls from playground equipment, } \\
\text { or collision, pushing, or shoving in } \\
\text { sports }\end{array}$ & 4 & 100 & 4 \\
\hline E880-E882, E883(.1,.2,.9), E884(.1,.2,.9), E885, E886.9, E888 & Other falls & 12534 & 10 & 1253 \\
\hline E917.0 & Struck by/against sports equipment & 32 & 100 & 32 \\
\hline E922.0-.9 & Firearm (unintentional) & 866 & 10 & 87 \\
\hline $\begin{array}{l}\text { E900(.0,.9), E901 }(.0, .8, .9) \text {, E902 }(.0, .8, .9) \text {, E903,E904.3, } \\
\text { E905-E909 }\end{array}$ & Natural/environmental factors & 1374 & 1.5 & 21 \\
\hline E848 & Other vehicles & 137 & 10 & 14 \\
\hline All other causes & & 140917 & 0 & 0 \\
\hline All injury causes & & 146941 & 4.1 & 6024 \\
\hline
\end{tabular}

*Based on data from the National Vital Statistics System of the National Center for Health Statistics, Hyattsville, MD.

tExternal cause of injury codes were selected based on methods used in previous studies. ${ }^{56}$

of the redesigned NHIS contains questions about both injury and poisoning. Data are collected from an adult member of the family ( 18 years or older) regarding all medically attended injury and poisoning episodes occurring in the previous three months for each person in the family. A parent or guardian responds for children under age 18. The 1997-99 NHIS collected detailed information about the four most recent injury episodes for each family member.

This study examines all medically attended SR injury episodes reported in a verbatim response to an Injury Section question. The injury episodes were defined as any traumatic event during the past three months that caused an injury or injuries from an external cause (for example, colliding, tripping, or falling) where (1) the injured person was participating in a SR activity and (2) the injury required treatment by a health care professional, either in person or by telephone. We included only episodes involving organized and unorganized sports (for example, basketball, football) or recreational activities (for example, biking, jogging, exercising); we excluded any leisure activities (for example, playing in yard, climbing a tree, gardening, rough housing). The injury diagnosis is the physical harm caused by the traumatic event, such as a sprain or fracture. An injury episode can have multiple injury diagnoses for the same person. Analysis by external cause of injury was based on the first listed mechanism of injury as determined by the International Classification of Diseases, Ninth revision, Clinical Modification (ICD-9-CM) external cause of injury codes (E codes). ${ }^{18}$

All episodes that included at least one health condition classified as an injury using the ICD-9-CM diagnosis codes 800-959 and 990-999 were included. Because children aged 4 years and younger do not routinely participate in SR activities in the same way that older children and adults do, more in-depth analysis of the data excluded this young age group.

An unweighted total of 1762 SR injury episodes were recorded for the three month recall period from 1997 through 1999. During the NHIS interview, participants were asked if they sustained injuries during the past three months that warranted medical attention (that is, advice including phone contact with a health care provider, or treatment). If the response was "yes", the respondent was asked a series of questions from the Injury Section of the NHIS survey. To categorize their activity at time of injury, respondents were asked a question on what they were doing when the injury episode occurred. Potential answers included: sports, leisure, unpaid work, or driving. They were asked to describe how the injury event happened and the answer was recorded as a verbatim response. In 1664 of these narratives, a sport or recreational activity was specified. Since ICD codes do not generally capture activity, ${ }^{19}$ we developed and applied a classification scheme for SR activities based on the International Classification of External Causes of Injury (ICECI). ${ }^{19}$ Two researchers independently classified each injury episode, and a third researcher reviewed these classifications and helped resolve any inconsistencies. For 98 injury episodes where narratives lacked details, activity was classified as "unspecified sport".

For comparative purposes, SR categories reported in this study were combined to match those used in a recent study of SR emergency department visits using data from the National Hospital Ambulatory Medical Care Survey (NHAMCS).

Annualized national estimates were computed by multiplying three month injury episode weights by four. Person weights used to calculate annualized weights accounted for the complex sample design and sampling ratios, were adjusted for non-response, and were post-stratified to the US population based on the US Bureau of Census totals for sex, age, and race/ethnicity for the year of the study. ${ }^{21}$ Since NHIS interviews were equally distributed across all four quarters of the year, no adjustment was made for seasonality.

The Barell injury diagnosis matrix ${ }^{22}$ of ICD-9-CM diagnosis codes was used to categorize episode related injury diagnoses by body part affected and type of diagnosis. The recommended framework for presenting injury data based on ICD-9-CM E codes was used to categorize injury episodes by mechanism of injury. ${ }^{23}$

Age adjusted rates were calculated using the year 2000 standard population. ${ }^{24}$ PROC RATIO of SUDAAN version 8.0.0 was used to obtain the estimated annualized rate of injury episodes per 1000 persons and the associated standard error. ${ }^{25}$ Annualized estimates and rates per 1000 population were 
Table 2 Estimated annual number and percentage of sports and recreational related injury episodes, rate per 1000 population, and $95 \%$ confidence intervals $(\mathrm{Cl})$, by selected characteristics: US, 1997-99

\begin{tabular}{|c|c|c|}
\hline Variable & No in $1000 \mathrm{~s}(\%)^{*}$ & Rate $(95 \% \mathrm{Cl})$ \\
\hline Total & 6975 (100.0) & 25.9 (24.4 to 27.4 ) \\
\hline \multicolumn{3}{|l|}{ Age in years } \\
\hline $0-4$ & $194(2.8)$ & 9.9 (7.2 to 12.6$)$ \\
\hline $5-14$ & $2384(34.2)$ & 59.3 (54.4 to 64.2$)$ \\
\hline $15-24$ & 2104 (30.2) & 56.4 (50.4 to 62.4$)$ \\
\hline $25-44$ & 1740 (24.9) & 21.0 (18.9 to 23.1$)$ \\
\hline $45+$ & $553(7.9)$ & $6.2(5.0$ to 7.4$)$ \\
\hline Males & 4767 (68.3) & 36.3 (33.9 to 38.7$)$ \\
\hline $0-4$ & 95 (2.0) & 9.4 (5.5 to 13.3$)$ \\
\hline $5-14$ & 1508 (31.6) & $73.3(66.1$ to 80.5$)$ \\
\hline $15-24$ & 1533 (32.2) & 81.4 (71.3 to 91.5$)$ \\
\hline $25-44$ & $1295(27.2)$ & 31.7 (27.8 to 35.6$)$ \\
\hline $45+$ & $337(7.1)$ & 8.2 (6.2 to 10.2$)$ \\
\hline Females & 2208 (31.7) & $16.0(14.6$ to 17.4$)$ \\
\hline $0-4$ & $99(4.5)$ & 10.3 (5.9 to 14.7$)$ \\
\hline $5-14$ & $876(39.7)$ & 44.7 (38.5 to 50.9 ) \\
\hline $15-24$ & $571(25.9)$ & 30.9 (24.6 to 37.2$)$ \\
\hline $25-44$ & $445(20.2)$ & 10.6 (8.6 to 12.6 ) \\
\hline $45+$ & $216(9.8)$ & 4.5 (3.2 to 5.8 ) \\
\hline \multicolumn{3}{|l|}{ Race } \\
\hline White & $6163(88.4)$ & 28.3 (26.7 to 29.9 ) \\
\hline Black & $484(6.9)$ & 14.5 (12.0 to 17.0$)$ \\
\hline Other & $327(4.7)$ & 18.1 (13.9 to 22.3 ) \\
\hline \multicolumn{3}{|l|}{ Location of injury } \\
\hline Sports facility & $2139(30.7)$ & 7.9 (7.1 to 8.7$)$ \\
\hline School & 1372 (19.7) & 5.1 (4.5 to 5.7$)$ \\
\hline Home (outside) & 1149 (16.5) & 4.3 (3.8 to 4.8$)$ \\
\hline Recreation area & $822(11.8)$ & $3.1(2.6$ to 3.6$)$ \\
\hline Street & $373(5.3)$ & 1.4 (1.1 to 1.7$)$ \\
\hline Body of water & $235(3.4)$ & $0.9(0.6$ to 1.2$)$ \\
\hline Other & 885 (12.7) & 3.2 (2.7 to 3.7$)$ \\
\hline \multicolumn{3}{|l|}{ Disposition } \\
\hline Hospitalized & $215(3.1)$ & $0.8(0.6$ to 1.0$)$ \\
\hline \multicolumn{3}{|l|}{ Lost 1 day from } \\
\hline School & $1086(20.0)$ & 4.0 (3.5 to 4.5$)$ \\
\hline Work & $1115(27.6)$ & 4.1 (3.6 to 4.6$)$ \\
\hline \multicolumn{3}{|c|}{ Assistance with activities } \\
\hline Personal care & $210(3.0)$ & 0.8 (0.6 to 1.0$)$ \\
\hline Regular routine & $16(0.2) t$ & - \\
\hline
\end{tabular}

considered unstable if the coefficient of variation was $30 \%$ or greater or if they were computed by using fewer than 20 unweighted cases for the three month recall period. Unstable estimates and rates are noted in the tables with a symbol.

\section{RESULTS}

From 1997 through 1999, Americans sustained an average annual estimate of 7.0 million SR injury episodes or 25.9 injury episodes per 1000 persons (95\% confidence interval 24.4 to 27.4 per 1000 persons) (table 2). Sixty four percent of these SR injury episodes occurred among persons ages 5-24 years. Injury episode rates were highest among the 5-14 year old (59.3 per 1000 persons) and the 15-24 year old age groups (56.4 per 1000 persons). Males sustained $68 \%$ of all SR injury episodes (36.3 per 1000 persons), more than twice the rate for females (16.0 per 1000 population). SR injury episode rates were consistently lower for females than for males for all age groups except for those aged 4 years or younger where the rates were similar for both sexes. The crude rate for females was highest in the 5-14 age group, while the crude rate for males was highest for the 15-24 age group. The age adjusted rate of injury events among whites (28.8 per 1000 population) was 1.5 times higher than that of black people ( 19.0 per 1000 population). Most SR injury episodes occurred at a sports facility $(30.7 \%)$, at school $(19.7 \%)$, or around the home (16.5\%). Three percent (0.8 per 1000 persons) of SR injury episodes required a hospital stay. Twenty percent of persons attending school lost one or more days resulting from their injury episode and $27.6 \%$ of those working lost one or more days for their injury event, and 3\% (0.8 per 1000 population) required help with personal care for six months or longer.

Further analysis focused on persons aged 5 years and older. For persons aged 5 years and older, an estimated 6.8 million or 27.2 episodes per 1000 persons occurred annually (table 3 ). Basketball was the most frequently mentioned SR activity (14.4\%), accounting for about four injury episodes per 1000 persons. Pedal cycling, recreational sports, exercising, and football were the next most common activities accounting for $36.6 \%$ of injury episodes. Males were most commonly injured while engaging in basketball, football, or pedal cycling activities, which accounted for $40.1 \%$ of all SR injury episodes. Among females, about $32 \%$ of all SR injury episodes occurred during exercising, gymnastics/cheerleading, or basketball.

The type of SR activity performed when the injury episode occurred also varied by age group (table 4 ). Pedal cycling was the most common SR activity associated with injury episodes among children aged 5-14 years. Basketball was the most frequently played sport among persons aged 15-24 years who sustained SR injuries. Persons 25 years of age and older were most frequently injured while participating in a recreational sport.

A majority of injury episodes from SR activities were to the upper $(31.2 \%)$ and lower $(38.9 \%)$ extremities (table 5$)$. For those that occurred to the lower extremities, $33.6 \%$ were to the 
Table 3 Estimated annual number and percentage of sports and recreational related injury episodes, rate per 1000 population, and $95 \%$ confidence interval (Cl) by type of activity and sex for persons aged 5 years and older: US, 1997-99

\begin{tabular}{|c|c|c|c|c|c|c|}
\hline \multirow[b]{2}{*}{ Activity } & \multicolumn{2}{|l|}{ Total } & \multicolumn{2}{|l|}{ Males } & \multicolumn{2}{|l|}{ Females } \\
\hline & $\begin{array}{l}\text { No in } \\
1000 \text { s (\%)* }\end{array}$ & $\begin{array}{l}\text { Rate } \\
(95 \% \mathrm{CI})\end{array}$ & $\begin{array}{l}\text { No in } \\
1000 \text { s (\%)* }\end{array}$ & $\begin{array}{l}\text { Rate } \\
(95 \% \mathrm{Cl})\end{array}$ & $\begin{array}{l}\text { No in } \\
1000 \text { s (\%)* }\end{array}$ & $\begin{array}{l}\text { Rate } \\
(95 \% \mathrm{CI})\end{array}$ \\
\hline Basketball & $977(14.4)$ & 3.9 (3.3 to 4.5$)$ & $777(16.6)$ & $6.4(5.4$ to 7.4$)$ & $199(9.4)$ & $1.6(1.1$ to 2.1$)$ \\
\hline Pedal cycling & $649(9.6)$ & $2.6(2.1$ to 3.1$)$ & $554(11.9)$ & $4.6(3.7$ to 5.5$)$ & $95(4.5)$ & 0.7 (0.4 to 1.0$)$ \\
\hline Recreational sport‡ & $647(9.5)$ & $2.6(2.2$ to 3.0$)$ & $461(9.9)$ & 3.8 (3.1 to 4.5$)$ & $185(8.8)$ & $1.4(1.0$ to 1.8$)$ \\
\hline Exercising & $614(9.1)$ & $2.5(2.1$ to 2.9$)$ & 359 (7.7) & $3.0(2.3$ to 3.7$)$ & $255(12.1)$ & $2.0(1.5$ to 2.5$)$ \\
\hline Football & $572(8.4)$ & 2.3 (1.9 to 2.7$)$ & $540(11.6)$ & 4.5 (3.7 to 5.3$)$ & $32(1.5)+$ & - \\
\hline Baseball/softball & $492(7.3)$ & $2.0(1.6$ to 2.4$)$ & $339(7.3)$ & $2.8(2.2$ to 3.4$)$ & $153(7.3)$ & $1.2(0.8$ to 1.6$)$ \\
\hline Soccer & $352(5.2)$ & $1.4(1.1$ to 1.7$)$ & $203(4.3)$ & 1.7 (1.2 to 2.2$)$ & $149(7.1)$ & $1.2(0.8$ to 1.6$)$ \\
\hline $\begin{array}{l}\text { Ice/roller skating/ } \\
\text { skateboarding }\end{array}$ & $342(5.0)$ & 1.4 (1.1 to 1.7$)$ & $187(4.0)$ & 1.5 (1.0 to 2.0$)$ & $155(7.4)$ & $1.2(0.8$ to 1.6$)$ \\
\hline Gymnastics/cheerleading & $302(4.5)$ & 1.2 (0.9 to 1.5$)$ & $80(1.7) \dagger$ & - & $222(10.5)$ & 1.7 (1.2 to 2.2$)$ \\
\hline Snow sports & $284(4.2)$ & $1.1(0.7$ to 1.5$)$ & $202(4.3)$ & 1.7 (1.1 to 2.3 ) & $82(3.9)+$ & - \\
\hline Playground equipment & $238(3.5)$ & $1.0(0.7$ to 1.3$)$ & $135(2.9)$ & $1.1 \quad(0.7$ to 1.5$)$ & $103(4.9)$ & $0.8(0.5$ to 1.0$)$ \\
\hline Water sports & $226(3.3)$ & 0.9 (0.7 to 1.1$)$ & $134(2.9)$ & $1.1(0.7$ to 1.5$)$ & $92(4.4)$ & 0.7 (0.4 to 1.0$)$ \\
\hline Combative sports & $180(2.7)$ & $0.7(0.5$ to 0.9$)$ & $152(3.3)$ & $1.3(0.8$ to 1.8$)$ & $28(1.3) \dagger$ & - \\
\hline Other individual sports $\ddagger$ & $493(7.3)$ & $2.0(1.6$ to 2.4$)$ & $321(6.9)$ & $2.6(2.0$ to 3.2$)$ & $173(8.2)$ & 1.3 (0.9 to 1.7$)$ \\
\hline Other team sports & $414(6.1)$ & 1.7 (1.3 to 2.1$)$ & $228(4.9)$ & $1.9(1.3$ to 2.5$)$ & $186(8.8)$ & $1.4(1.0$ to 1.8$)$ \\
\hline Total & $6781(100.0)$ & 27.2 (25.6 to 28.8 ) & $4672(100.0)$ & 38.5 (36.0 to 41.0 ) & $2108(100.0)$ & 16.5 (14.9 to 18.1$)$ \\
\hline
\end{tabular}

*Numbers and percentages may not sum to total due to rounding.

tEstimates may be unstable because they are based on $<20$ cases or the coefficient of variation $>30 \%$.

†Recreational sports includes tennis, racquetball, badminton and other racquet sports, as well as golf, bowling, fishing, hunting, hiking, mountain climbing and other leisure sports; other individual sports includes all other sport recreation categories; for example, horseback riding, all-terrain vehicle, frisbee, and catch; and other team sports includes volleyball, rugby, hockey, lacrosse, cricket, and others.

lower leg or ankle. The hands, wrists, or fingers were affected in $51.5 \%$ of the injuries to the upper extremities and another $26.4 \%$ of injuries were to the shoulder or upper arm. An estimated 1.1 million SR episode related injuries involve the head or neck region, of which $17.2 \%$ were internal head injuries.

Strains and sprains were the most frequent injury diagnosis (31.5\%) followed by fractures (22\%). Among those with head or neck injuries, the most frequent injury diagnosis was an open wound $(56.1 \%)$. Among persons with extremity injuries, strains/sprains, and fractures accounted for $69.4 \%$ of injuries. The most common mechanisms of injury were struck by/against, fall, and overexertion accounting for $75 \%$ of the SR injury episodes.

For SR injuries for persons aged 5-24 years, annualized national estimates of injury episodes reported in NHIS were $41.7 \%$ higher than national estimates of injury related emergency department visits based on data from NHAMCS (table 6). The percentage difference varied by type of activity ranging from 81.9 for recreational sport injuries to almost no difference for pedal cycling and water sports.

\section{DISCUSSION}

This study is among the first to examine all medically attended injuries from SR activities across all age groups in the US. The rate of 25.9 injury episodes per 1000 persons associated with SR activities was greater than the rate for transportation related injury episodes in 1997. ${ }^{17}$ Our results highlight the number of SR injury episodes where the injured person received medical attention beyond treatment in a hospital emergency department and demonstrate the importance of broad surveillance and prevention activities. For persons aged 5-24 years, an estimated $10.7 \%$ of all injury related emergency department visits were for SR activities based on NHAMCS data $^{7}$ compared with $22.1 \%$ of all SR injury episodes in our study. Our study indicates that about $42 \%$ of persons aged 5-24 years receiving medical attention for an SR injury did not go to an emergency department. Also, the annualized estimate of 7 million injury episodes in our study is 1.6 times higher than the 4.3 million injuries treated in US hospital emergency departments based on the National Electronic Injury Surveillance System All Injury Program. ${ }^{1}$ One fifth of schoolchildren

Table 4 Estimated annual number (in 1000s) of injury episodes/rate per 1000 persons ( $95 \%$ confidence interval), by leading types of sports and recreational related activities and age for persons aged 5 years and older: US, 1997-99

\begin{tabular}{|c|c|c|c|}
\hline Rank & $5-14$ years & $15-24$ years & $25+$ years \\
\hline 1 & Pedal cycling & Basketball & Recreational sport* \\
\hline & $332 / 8.3(6.4$ to 10.1$)$ & $440 / 11.8$ (9.2 to 14.4 ) & $370 / 2.1 \quad(1.7$ to 2.6$)$ \\
\hline 2 & $\begin{array}{l}\text { Basketball } \\
261 / 6.5 \text { (4.7 to } 8.3 \text { ) }\end{array}$ & $\begin{array}{l}\text { Football } \\
287 / 7.7 \text { (5.8 to } 9.6)\end{array}$ & $\begin{array}{l}\text { Exercising } \\
331 / 1.9(1.5 \text { to } 2.4)\end{array}$ \\
\hline 3 & $\begin{array}{l}\text { Football } \\
243 / 6.0 \text { (4.6 to } 7.5)\end{array}$ & $\begin{array}{l}\text { Exercising } \\
172 / 4.6(3.0 \text { to } 6.2)\end{array}$ & $\begin{array}{l}\text { Basketball } \\
276 / 1.6 \text { (1.2 to } 2.0)\end{array}$ \\
\hline 4 & $\begin{array}{l}\text { Playground equipment } \\
219 / 5.4 \text { (3.9 to } 7.0 \text { ) }\end{array}$ & $\begin{array}{l}\text { Soccer } \\
145 / 3.9(2.4 \text { to } 5.4)\end{array}$ & $\begin{array}{l}\text { Pedal cycling } \\
231 / 1.3(0.9 \text { to } 1.8)\end{array}$ \\
\hline 5 & $\begin{array}{l}\text { Baseball/softball } \\
185 / 4.6 \text { (3.3 to 6.0) }\end{array}$ & $\begin{array}{l}\text { Recreational sport* } \\
123 / 3.3 \text { (2.0 to } 4.6)\end{array}$ & $\begin{array}{l}\text { Baseball/softball } \\
205 / 1.2 \text { (0.8 to } 1.5)\end{array}$ \\
\hline Remainder & 1144 & 937 & 880 \\
\hline Total & $2384 / 59.3$ (54.4 to 64.2 ) & $2104 / 56.4$ (50.4 to 62.4$)$ & $2293 / 13.3(12.1$ to 14.5$)$ \\
\hline
\end{tabular}

*Includes tennis, racquetball, badminton and other racquet sports, as well as golf, bowling, fishing, hunting, hiking, mountain climbing, and other leisure sports. 
Table 5 Estimated annual number of episode related injury diagnoses* by body part and type of diagnosis, and percentages, overall and by body part affected for persons aged 5 years and older: US, 1997-99

\begin{tabular}{|c|c|c|c|}
\hline & $\begin{array}{l}\text { Diagnoses (in } \\
1000 \mathrm{~s}) \dagger\end{array}$ & $\begin{array}{l}\text { Overall } \\
(\%) \dagger\end{array}$ & $\begin{array}{l}\text { Body part } \\
(\%) t\end{array}$ \\
\hline Head/neck & 1109 & 14.8 & 100.0 \\
\hline Open wound & 622 & 8.3 & 56.1 \\
\hline Internal organs & 191 & 2.5 & 17.2 \\
\hline Superficial/contusions & 165 & 2.2 & 14.9 \\
\hline Fracture & $67 \ddagger$ & 0.9 & 6.0 \\
\hline Unspecified & $64 \ddagger$ & 0.9 & 5.8 \\
\hline Torso & 577 & 7.7 & 100.0 \\
\hline Sprains/strains & 164 & 2.2 & 28.4 \\
\hline Superficial/contusions & 141 & 1.9 & 24.4 \\
\hline Fracture & 120 & 1.6 & 20.8 \\
\hline Internal organs & $14 \neq$ & 0.2 & 2.4 \\
\hline Open wounds & $7 \ddagger$ & 0.1 & 1.2 \\
\hline Crushing & $6 \neq$ & 0.1 & 1.0 \\
\hline Unspecified & 125 & 1.7 & 21.7 \\
\hline Upper extremities & 2342 & 31.2 & 100.0 \\
\hline Fracture & 998 & 13.3 & 42.6 \\
\hline Sprains/strains & 627 & 8.4 & 26.8 \\
\hline Superficial/contusions & 219 & 2.9 & 9.4 \\
\hline Dislocations & 135 & 1.8 & 5.8 \\
\hline Open wounds & 131 & 1.7 & 5.6 \\
\hline Crushing & $17 \ddagger$ & 0.2 & 0.7 \\
\hline Amputations & $8 \ddagger$ & 0.1 & 0.3 \\
\hline Burns & $7 \ddagger$ & 0.1 & 0.3 \\
\hline Nerves & $6 \ddagger$ & 0.1 & 0.3 \\
\hline Unspecified & 193 & 2.6 & 8.2 \\
\hline Lower extremities & 2922 & 38.9 & 100.0 \\
\hline Sprains/strains & 1566 & 20.9 & 53.6 \\
\hline Fracture & 464 & 6.2 & 15.9 \\
\hline Superficial/contusions & 285 & 3.8 & 9.8 \\
\hline Open wounds & 196 & 2.6 & 6.7 \\
\hline Dislocations & 109 & 1.5 & 3.7 \\
\hline Amputations & $11 \neq$ & 0.1 & 0.4 \\
\hline Blood vessels & $4 \ddagger$ & 0.1 & 0.1 \\
\hline Unspecified & 286 & 3.8 & 9.8 \\
\hline Other body parts $\S$ & 553 & 7.4 & 100.0 \\
\hline Total & 7503 & 100.0 & \\
\hline
\end{tabular}

*Includes $8.6 \%$ of injury episodes that involved more than one diagnosis.

†Numbers and percentages may not sum to total due to rounding. \# Estimates may be unstable because they are based on $<20$ cases or the coefficient of variation $>30 \%$.

§lncludes injuries to the spine and back, other multiple/unspecified body parts, and late effects.

lost one or more days of school because of their injury or injuries, and more than one quarter of working adults lost one or more work days due to the injury event. This extent of lost activity emphasizes the burden that SR injuries place on our society and the health care system.

Our study findings suggest that prevention programs aimed at reducing SR injuries through targeting high risk activities, places of occurrence, risk behaviors, ${ }^{26}$ and use of protective devices need to go beyond focusing on children and also consider physically active adults. In this study, two thirds of injuries occurred among 5-24 year olds. However, one quarter of the injuries occurred among 25-44 year olds. The common activities involved with injury episodes in the latter age group include recreational sports (for example, racket sports, golf, bowling) and exercising (for example, jogging, walking, aerobics). The participants greater than 25 years are not often targeted in injury prevention efforts. For instance, no state and only 29 localities currently have bicycle helmet laws covering adults $^{27}$ despite the Healthy People 2010 objective supporting such laws. ${ }^{28}$

Half of the injuries reported in this study occurred at a school or sports facility. Policies and programs to promote the use of effective interventions such as protective gear (for example, appropriate gear in team sports, racquetball eye pro-
Table 6 Average annual numbers of sports and recreation related injury episodes and injury emergency department (ED) visits and percent difference, by type of activity for persons aged 5-24 year olds from NHIS and NHAMCS: US, 1997-99

\begin{tabular}{|c|c|c|c|}
\hline Activity & $\begin{array}{l}\text { NHIS } \\
1997-99 \\
\text { (No of } \\
\text { episodes* in } \\
\text { 1000s) }\end{array}$ & $\begin{array}{l}\text { NHAMCS } \\
1997-98 \\
\text { (No of ED } \\
\text { visits* in } \\
1000 \text { s) }\end{array}$ & $\begin{array}{l}\% \\
\text { Difference }\end{array}$ \\
\hline All sports/recreation & 4488 & 2616 & 41.7 \\
\hline Group sport & 2064 & 1170 & 43.3 \\
\hline Basketball & 701 & 447 & 36.2 \\
\hline Football & 530 & 271 & 48.9 \\
\hline Baseball/softball & 288 & 245 & 14.9 \\
\hline Soccer & 268 & 95 & 64.6 \\
\hline Other team sports $\neq$ & 277 & 112 & 59.6 \\
\hline Individual sport & 2423 & 1446 & 40.3 \\
\hline Pedal cycling & 417 & 421 & -1.0 \\
\hline $\begin{array}{l}\text { Ice or roller skating, } \\
\text { skateboarding }\end{array}$ & 254 & 150 & 40.9 \\
\hline Gymnastics/cheerleading & 254 & 146 & 42.5 \\
\hline Playground & 226 & 137 & 39.4 \\
\hline Snow sport & 136 & 111 & 18.4 \\
\hline Water sport & 101 & 100 & 1.0 \\
\hline Exercising & 283 & 94 & 66.8 \\
\hline Combative & 124 & 61 & 50.8 \\
\hline Recreational sportł & 277 & 50 & 81.9 \\
\hline Other sport‡ & 351 & 178 & 49.3 \\
\hline
\end{tabular}

* Numbers may not sum to total due to rounding.

$\uparrow \%$ difference $=(\mathrm{NHIS}$ estimate- $\mathrm{NHAMCS}$ estimate) $/ \mathrm{NHIS}$ estimate $\times$ 100.

‡Other team sports includes volleyball, rugby, hockey, lacrosse, cricket and others; recreational sports includes tennis, racquetball, badminton and other racquet sports, as well as golf, bowling, fishing, hunting, hiking, mountain climbing and other leisure sports; and other sports includes all other sport recreation categories; for example,

horseback riding, all-terrain vehicle, frisbee, and catch.

tection) and enforcement of rules of play designed for safety (for example, prohibiting slide tackles from behind in soccer or spearing and clipping in football) need to be implemented and evaluated to determine if these policies can bring about a decrease in injuries at these common sporting sites. ${ }^{28}$

Bicycling and exercising (which includes walking and jogging) were common activities associated with $19 \%$ of the injuries reported. These activities require safe outdoor environments. Specific strategies have been developed for use by policy makers, educators, advocates, transportation experts, health and injury professionals, and others with an interest in promoting safe bicycling..$^{29}$ These strategies should be actively promoted, implemented, and evaluated.

Our national estimates were consistently higher than those for emergency department visits using NHAMCS emergency department data for all sports except pedal cycling and water sports. Higher estimates using NHIS data may be expected because some injured persons seek treatment and medical advice at health care facilities other than hospital emergency departments. However, the differences may partially be the result of using different methodologies to obtain the data; the NHAMCS data are abstracted from medical records from a national probability sample of hospital emergency department visits; the NHIS data are from a national household survey.

Our study reports a SR injury rate of 59.3 injury episodes per 1000 children among 5-14 year olds. A recently published study of NHIS data about leisure and SR activities among 6-17 year olds found an estimated 91.2 injury episodes per 1000 children. ${ }^{8}$ The previous study used a broader definition that included leisure activities and a different age range; however, their findings further illustrate the burden on the health care system from injuries sustained from activities associated with a healthy lifestyle. 


\section{Key points}

- This study is among the first to examine nationally representative estimates of SR injury events for all age groups in the civilian US population. The rate of injury is substantial among persons of all ages, especially for 5-24 year olds.

- Of those receiving medical attention, one fifth of schoolchildren and more than one quarter of working adults experienced one or more days of lost time from school or work, respectively. This loss of activity illustrates the burden of SR injuries on our society and on the health care system.

- As more adults strive for a healthy lifestyle by engaging in SR activities, prevention efforts to reduce SR injuries need to extend beyond children's activities and target high risk activities among physically active adults.

- Population based surveys need to capture exposure information along with data on SR injuries, places of occurrence, high risk behaviors, and use of protective devices for person of all ages. SR injury (or injury episode) rates per exposure time are needed to (1) compare risks of injury among activities and (2) help set priorities and make recommendations relevant to prevention program for sports and recreation activities.

The ICD codes have traditionally been used to classify injury incidents treated in health care settings. ${ }^{18}$ However, these codes do not routinely capture the activity of a person at the time of injury. Injury professionals, under the auspices of the World Health Organization, have developed an improved tool for characterizing injury information-the ICECI classification scheme. ${ }^{19}$ The ICECI helps researchers and prevention practitioners better describe the types of injuries and the circumstances surrounding the injury incident. We were able to classify all but 98 (5.6\%) of the 1762 recorded narratives as a particular SR activity by using the ICECI classification scheme. The remaining 98 lacked specificity in the narrative description of the incident.

The Barell injury diagnosis matrix is a useful tool for presenting uniform data by nature of injury and body part affected. ${ }^{22}$ This matrix was easily adapted to categorize ICD-9-CM diagnosis codes used to classify type of diagnosis and body part affected for NHIS cases to provide national estimates.

This study has several limitations. We are unable to compare risks among different activities because the NHIS data lack exposure information. To determine the actual risk of a SR injury event, information about each participant's exposure to the particular SR activity is needed. ${ }^{30}$ For instance, in our study, four injury episodes per 1000 population resulted from playing basketball. However, information on how often basketball was played either in practice, in competition, or for recreation for injured persons was not obtained during the household interview. Basketball may be a higher risk activity, have more participants, or have participants who play more often or for longer periods than do other activities.

Information obtained retrospectively from proxy reports may be subject to recall bias. ${ }^{31}$ Another limitation is the possible effect of seasonality associated with a three month recall period. Since household interviews in NHIS are conducted year round, multiplying sample weights by four to compute annualized estimates seems reasonable for most SR activities, but may overestimate injury episodes of certain seasonal sports, such as snow skiing.

\section{IMPLICATIONS FOR PREVENTION}

The incidence of SR injuries is substantial, particularly among persons ages 5-24 years. Data from our study suggest that many people are commonly treated for SR injuries in health care facilities other than hospital emergency departments, including clinics and doctors' offices. These settings provide the opportunity to educate participants about injury prevention in SR activities. ${ }^{32} 33$ As health professionals continue to promote physical activity and Americans remain active as adults, further injury prevention efforts need to be promoted and evaluated. ${ }^{28} 2934$ Policies and programs to enforce the use of appropriate safety gear at schools and sports facilities, active community effort focusing on safe outdoor recreation (for example, promotion of bike paths or lanes, sidewalks, and cross walks), and laws that promote safety in SR activities for persons of all ages (for example, requiring all bicycle riders to wear helmets) are just examples of possible prevention strategies. Additionally, development of a standard instrument to capture exposure information along with SR injuries in population based surveys, such as NHIS, are needed. These data can be used to compute injury (or injury episode) rates per exposure time to compare risks of injury among activities, to help set priorities and to develop further recommendations for SR injury prevention research and programs.

\section{ACKNOWLEDGEMENT}

We thank Marcie-jo Kresnow, MS for her statistical advice, and Karen Gotsch, MPH and Helen Jakimenko for their statistical assistance.

\section{Authors' affiliations}

J M Conn, J L Annest, J Gilchrist, National Center for Injury Prevention and Control, Centers for Disease Control and Prevention, Atlanta, Georgia

\section{REFERENCES}

1 Gotsch K, Annest JL, Holmgreen P, et al. Nonfatal sports- and recreation-related injuries treated in emergency departments-United States, July 2000-June 2001. MMWR Morb Mortal Wkly Rep 2002; 51 :736-40.

2 Mummery WK, Spence JC, Vincenten JA, et al. A descriptive epidemiology of sport and recreation injuries in a population-based sample: results from the Alberta Sports and Recreation Injury Survey (ASRIS). Can J Public Health 1998;89:53-6.

3 Belechri M, Patridou E, Kedikoglou S, et al. Sports injuries among children in six European union countries. Eur J Epidemiol 2001;17:1005-12.

4 Stephenson MR, Hamer P, Finch CF, et al. Sport, age, and sex specific incidence of sports injuries in Western Australia. Br J Sports Med 2000;34: 188-94

5 Kraus JF, Conroy C. Mortality and morbidity from injuries in sports and recreation. Annu Rev Public Health 1984;5:163-92.

6 Fingerhut LA, Warner M. Injury chartbook. Health, United States, 1996-97. Hyattsville, MD: National Center for Health Statistics, 1997.

7 Burt CW, Overpeck MD. Emergency visits for sports-related injuries. Ann Emerg Med 2001;37:301-8.

$8 \mathrm{Ni} \mathrm{H}$, Barnes P, Hardy AM. Recreational injury and its relation to socioeconomic status among school aged children in the US. Inj Prev 2002;8:60-5

9 Bijur PE, Trumble A, Harel Y, et al. Sports and recreation injuries in US children and adolescents. Arch Pediatr Adolesc Med 1995; 149:100916.

10 Cheng TL, Fields CB, Brenner RA, et al. Sports injuries: an important cause of morbidity in urban youth. Pediatrics 2000;105:e32. Available at: http://www.pediatrics.org/cgi/content/full/105/3/e32 laccessed 4 March 2003).

11 Danseco ER, Miller TR, Spicer RS. Incidence and costs of 1987-1994 childhood injuries: demographic breakdown. Pediatrics 2000;105:e27. Available at: http://www.pediatrics.org/cgi/content/full/105/2/e27 (accessed 4 March 2003).

12 McLain LG, Reynolds S. Sports injuries in a high school. Pediatrics 1989:84:446-50

13 Purvis JM, Burke RG. Recreational injuries in children: incidence and prevention. J Am Acad Orthop Surg 2000;9:365-74.

14 Taylor BL, Attia MW. Sports-related injuries in children. Acad Emerg Med 2000;7:1376-82.

15 US Consumer Product Safety Commission. Baby boomer sports injuries. Washington, DC: US Consumer Product Safety Commission, 2000

16 US Consumer Product Safety Commission. Sports-related injuries to persons 65 years of age or older. Washington, DC: US Consumer Product Safety Commission, 1998

17 Warner M, Barnes PM, Fingerhut LA. Injury and poisoning episodes and conditions: National Health Interview Survey, 1997. Vital Health Stat 2000;10(202):2-5

18 US Department of Health and Human Services. Generic ICD-9-CM. Hospital version 1999. Reno, NV: Channel Publishing, 1998. 
19 Consumer Safety Institute. Data dictionary: international classification of external causes of injuries (ICECI). Version 1 0 . Amsterdam, Netherlands: Consumer Safety Institute, 2001.

20 US Department of Health and Human Services, Centers for Disease Control and Prevention, National Center for Health Statistics. 1999 National Health Interview Survey (NHIS) public use data release. NHIS survey description. Hyattsville, MD: National Center for Health Statistics, February, 2002. Available at: http://www.cdc.gov/nchs/ nhis.htm\#Methods (accessed 4 March 2003)

21 Botman SL, Moore TF, Moriarity CL, et al. Design and estimation for the National Health Interview Survey, 1995-2004. Hyattsville, MD: National Center for Health Statistics. Vital Health Stat 2(130), DHHS Publication No (PHS) 2000-1330, 2000.

22 Barell V, Aharonson-Daniel L, Fingerhut LA, et al. An introduction to the Barell body region by nature of injury diagnosis matrix. Inj Prev 2002;8:91-6

23 Centers for Disease Control and Prevention. Proposed matrix of E-code groupings for presenting injury mortality and morbidity data. Atlanta, GA: National Center for Injury Prevention and Control,2002. Available at: http://www.cdc.gov/ncipc/whatsnew/matrix2.htm (accessed 4 March 2003).

24 US Department of Health and Human Services, Centers for Disease Control and Prevention, National Center for Health Statistics, National Vital Statistics System. Age-adjusted death rates: trend data based on the year 2000 standard population. National Vital Statistics Report 21 September 2001;49(9):2

25 Research Triangle Institute. SUDAAN user manual release 8.0.0. Research Triangle Park, NC: Research Triangle Institute, 2001
26 Pickett W, Garner M, Boyce WF, et al. Gradients in risk for youth injury associated with multiple-risk behaviours: a study of 11,329 Canadian adolescents. Soc Sci Med 2002:55: 1055-68.

27 Bicycle Safety Institute. Available at: http://www.bhsi.org/ bike_law.htm (accessed 4 March 2003).

28 US Department of Health and Human Services. Healthy people 2010. 2nd Ed. With understanding and improving health and objectives for improving health. 2 Vols. Washington, DC: US Government Printing Office, 2000. Available at: http://www.health.gov/healthypeople (accessed 4 March 2003)

29 National Highway Traffic Safety Administration, Centers for Disease Control and Prevention, Federal Highway Administration. National strategies for advancing bicycle safety. Washington, DC: US Department of Transportation, National Highway Traffic Safety Administration, 2001

30 de Loes M. Exposure data: why are they needed? Sports Med 1997:24:172-5.

31 Harel $Y$, Overpeck MD, Jones DH, et al. The effects of recall on estimating annual nonfatal injury rates for children and adolescents. Am J Public Health 1994:84:599-605.

32 American Academy of Orthopedic Surgeons. Prevent injuries America. Available at: http://orthoinfo.aaos.org/ prevention.cfm?category=Prevention (accessed 4 March 2003).

33 American Orthopedic Society for Sports Medicine. Available at: http://www.aossm.org/Publications (accessed 4 March 2003).

34 US Department of Health and Human Services. The Surgeon General's call to action to prevent and decrease overweight and obesity. Rockville, MD: US Department of Health and Human Services, Public Health Service, Office of the Surgeon General;2001. Available at: http://www.surgeongeneral.gov/topics (accessed 4 March 2003).

\section{LACUNAE}

\section{Super Bowl risks}

A

etter in the New England Journal of Medicine finds that there is a $41 \%$ greater chance of a car crash in the four hours after the Super Bowl game in the US than at any other time... including new year. Although, predictably, alcohol figures heavily, the authors also blame fatigue and driver distraction. The most intriguing aspect of the report is that the risks are greater in the states of the losing teams but applies equally to both sexes and all age groups (Redelmeier DA, Stewart CL. Driving fatalities on Super Bowl Sunday. N Engl J Med 2003;348:368-9).

\section{Stomach starter}

A mother whose baby swallowed part of her electronic car key managed to start her car by pressing the boy's stomach close to the steering wheel as she turned the key. She had called her breakdown service when her car refused to start after a shopping trip. The mechanic thought the battery was flat but then noticed that part of the key-a tiny radio transponder-was missing. Baby Oscar was the chief suspect, so the mechanic suggested a solution. "She sat him on her lap and made sure that his tummy was pressed against the wheel" he said. "She turned the key and the car started. It was the oddest breakdown I have been to" (from Sunday Times (London), contributed by Mike Hayes).

\section{Dry snowmobiles?}

This is a man-bites-dog story: Generally, special interest groups (like the NRA) tend to oppose regulations affecting the safety of their members. In an unusual twist, after four deaths involving snowmobilers in Quebec, it was snowmobile clubs that called on the government to make it illegal to use a snowmobile after consuming alcohol. And, in a step larger than that applied to car drivers, they pushed for zero as the limit! In his infinite wisdom, the junior transport minister disagreed, preferring to "educate, sensitize, and persuade". Evidence based policy making, indeed! (contributed by Barry Pless). 